\title{
REMNANT SURFACES IN THE TÁRKÁNY BASIN
}

\section{PÉTER PECSMÁNY*, ANDRÁS HEGEDÚS, JÁNOS VÁGÓ}

University of Miskolc, Department of Physical Geography and Environmental Science, Miskolc, Hungary

*Email: ecopeter@uni-miskolc.hu

Received 2 June 2020, accepted in revised form 12 July 2020

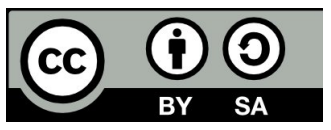

\begin{abstract}
The terraces of the Tárkány Basin, located in the SW part of the Bükk Mountains are known since the beginning of the 20th century. Based on field surveys, six morphological levels were delineated and described in 1936. During the later geological mapping surveys, three gravel terraces had been mapped in the basin. Since then, no comprehensive morphological mapping has been made in the Tárkány Basin. Our study aimed to validate the results of these early studies using a digital elevation model. We delineated the remnant surfaces of the basin by morphometric and GIS techniques. Then, based on field surveys and former geological maps; we characterised these remnant surfaces, and their area was measured as well. The aim of study is the comparison of the results of traditional and GIS based methods which contribute to a better understanding of the surface evolution of the basin and its surroundings.
\end{abstract}

Keywords: remnant surfaces, terrace, pediment, GIS, morphometry, geomorphological mapping, geomorphological levels, Bükkalja, Tárkány Basin, DEM

\section{Introduction}

The terraced valleys of Bükkalja were observed since the 19th century by geologists and geomorphologists (Schréter, 1912; Kerekes, 1936; Pinczés, 1955, 1957; Krolopp et al., 1989; Dobos \& Mester, 2018). However, the Hungarian terrace research had already progressed significantly in its methodology and envisaged the validating of early works, e.g. Kerekes, 1936. During our terrace morphological research in Bükkalja, we often encountered the different approaches used by various researchers. This influenced the classification and mapping of terraces due to the technical development of early ages, which made it difficult for us to handle the terrace surfaces of the micro-region into a unified system (Pecsmány, 2017).
In the first phase of our work, we reevaluated the remnant surfaces of Tárkány Basin, which were mapped at the beginning of the last century. We analysed the terrace map of Kerekes (1936) using GIS methods. Then, based on the geological mapping of the last decades (Less et al., 2002) and our fieldwork, we delineated and re-evaluated the remnant surfaces and possible terraces of the basin using experimental morphometric methods performed on a digital surface model.

\section{Materials and Methods}

\section{Research area}

Based on the academic landscape classification, the examined area is located in the SW part of the central region of the North 


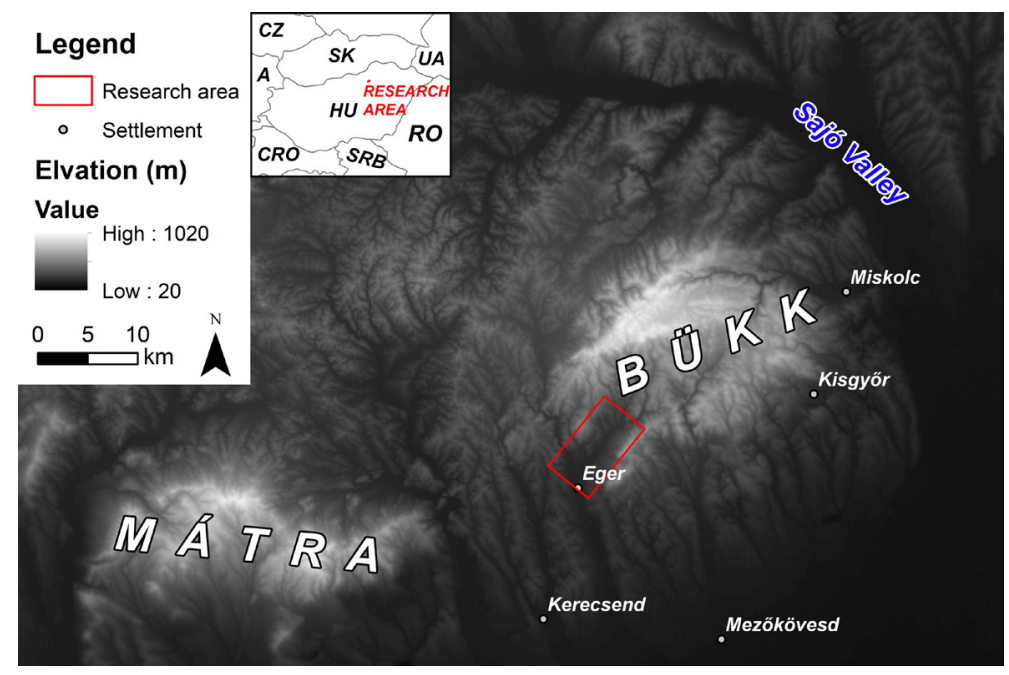

Fig. 1. Map of the research area and its surroundings (Source: EUDEM

Hungarian Mountains, called Bükkvidék. The basin can be interpreted as a micro-region, surrounded by the SW part of the Bükk Mountains (Dövényi, 2010) (Figure 1).

The area covers $46.39 \mathrm{~km} 2$, and its topography varies between $167 \mathrm{~m}$ and 662 $\mathrm{m}$ above sea level with its average height is $276 \mathrm{~m}$, and its average relative relief is 164 $\mathrm{m}$. Previous studies characterised the area as a Pleistocene denudation basin (Dövényi, 2010), however, based on the latest studies, the area is a structural basin, which is observed to be seismically active (Petrik, 2016; Katona, 2017; Pecsmány, 2020). The edge of the basin consists of Mesozoic sedimentary (Hámor Dolomite Formation, Felsőtárkány Limestone Formation, Berva Limestone Formation, Lökvölgy Formation) and volcanic (Várhegy Formation) rocks. Moving towards the centre of the basin, younger rocks can be found. The NE side consists of the Felnémet Rhyolite Tuff Formation, with a very high (3-40\%) clinoptiolite content indicative of a zeolite formation. Occasionally, clay marl and sand can also be found (Less et al., 2002, 2005). The slopes are covered by flat-worn shale and radiolarite debris of the terraces running parallel to the Tárkány Creek. The geological mapping studies so far separated three levels of gravel terraces, located one above the other (Less et al., 2005; Gulácsi, n.d.). During the topological and geological mapping of recent years, we managed to uncover numerous minor errors in these geological maps (Gál et al., 2018, 2019); therefore we also verified the remnant surfaces on the maps of Less et al. (2005) and Gulácsi (n.d.) by fieldwork.

In the last century, Kerekes (1936) carried out detailed terrace morphological research in the basin (Figure 2.a). Since then, there has been no comprehensive topological study of the entire basin. During his field trips, Kerekes (1936) managed to separate one alluvial embankment, four gravel and one rock terrace level. At a relative height of 5-6 meters, he considered the terrace level No. I. to be a Holocene embankment, which was not shown on the map. Terrace No. II. has been identified as a gravel terrace with a relative height of $6-10 \mathrm{~m}$. In the case of terrace No. III. he mentioned that this level was also marked by Schréter (1912) on his geological map (Figure 2.b). It was placed at a relative height of 5-6 $\mathrm{m}$ above the valley bottom of the Tárkány Creek. The relative height of terrace No. IV. decreases to 18 m. Kerekes (1936) described the No. V. gravel terrace at a relative height of 60-85 m. The highest, No. VI. rock 

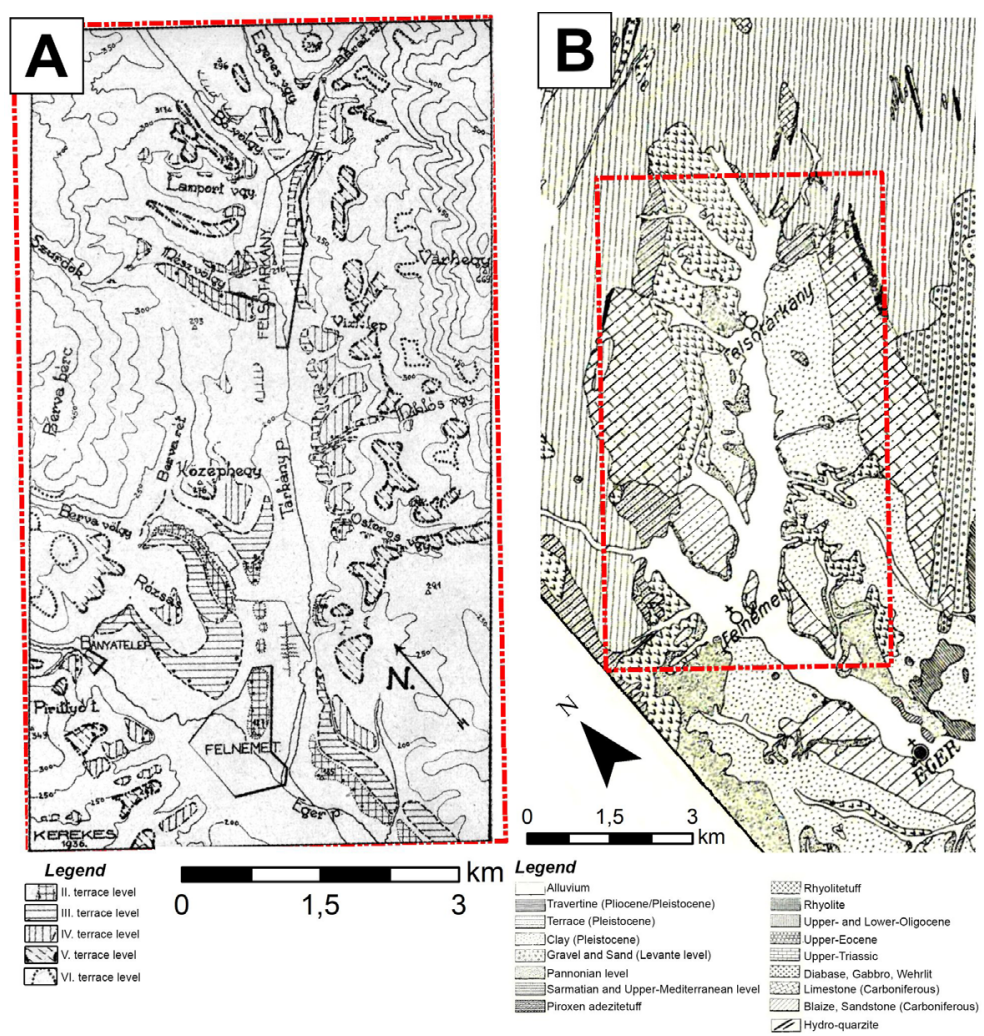

Fig. 2. Terrace map from Kerekes (1936) (A), Geological map from Schréter (1912) (B)

terrace with a relative height of 100-140 m, can be investigated on the side of Nagy-Egedhill and Várhegy (Kerekes, 1936). Later in the geological atlas of the city of Eger, Balogh et al., (1974) marked three terrace levels in the southern part of the Tárkány Basin.

\section{Methods}

In our investigations, we used geological (Less et al., 2002) observation (Gulácsi n.d.) and geomorphological (Kerekes, 1936) maps. The map of the southern part of the basin made by Balogh et al. (1974) depicts the terrace surfaces as lines, so we could not use this map in our studies. The geological and topographical maps were georeferenced, and then the terraces have been digitised. Then we examined the relative and absolute height of the surfaces using the $25 \mathrm{~m}$ spatial resolution HydroDEM digital surface model, which was created from interpolated and remotely sensed data. The terraces on the right side of the Eger stream were not taken into account in this study.

\section{Digital geomorphological map}

In the research we applied several built-in landform classification algorithms (Condrad, 2011,2013), howeverwefound that theresults of these methods are not reliable according to our field investigations. Therefore we used new GIS based classification method. During the preparation of our geomorphological map, we delineated the hilltops and remnant surfaces using the HydroDEM. This process was done as follows: We created the TPI (Topography Position Index) map of the area from HydroDEM using a $500 \mathrm{~m}$ radius cell environment (more: Weiss, 2001; Jenness, 2006). Then we reclassified the TPI layer by assigning value „1, to pixels with greater pixel value than 0 , while pixels with a value less than 0 were given as "NoData". Applying this method, we managed to obtain the 

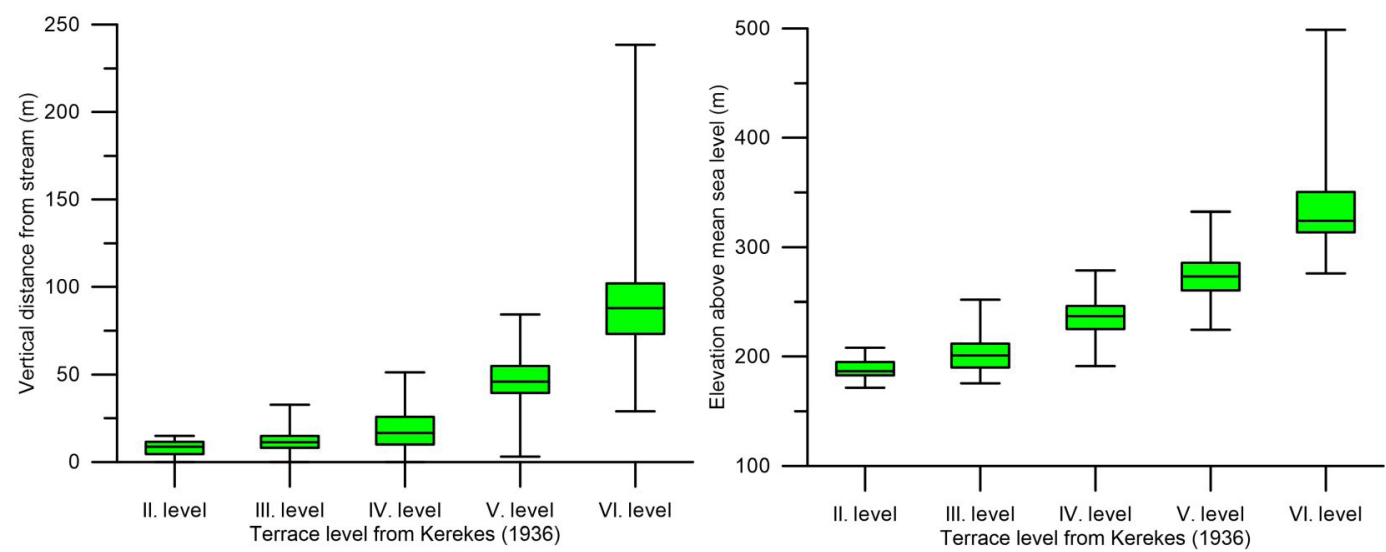

Fig. 3. Height distribution of terraces mapped by Kerekes (1936)
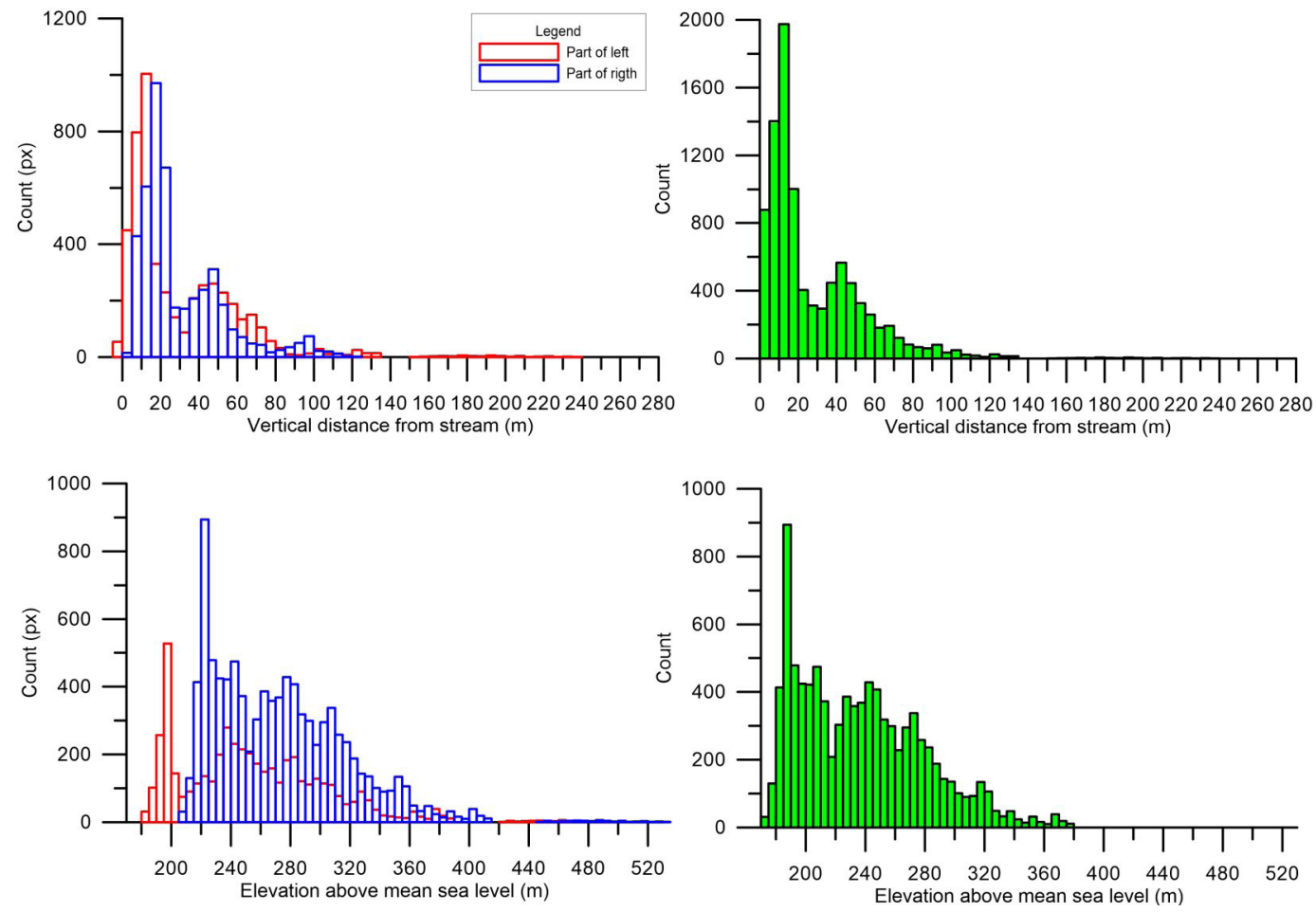

Fig. 4. Relative height and elevation of terraces mapped by Kerekes (1936) on the left(blue) and right

(red)sides of the valley, and altogether (green)

hilltops, gentle segments of slopes, and slopes. Subsequently, hilltops and the gentle segments of slopes, which are the possible remnant surfaces have been selected from this reclassified layer by removing the areas with a slope greater than $5^{\circ}$. The slopes were classified into four categories based on their slope angle. The areas along the permanent streams with a relative height of maximum 5 $\mathrm{m}$ were considered as valley bottoms.

\section{Results}

\section{Analysis of the actual terrace heights mapped by former geomorphological examinations}

There is a contradiction in, Kerekes' (1936) work, which is well reflected in the boxplot diagrams made from the height values of terrace surfaces marked by him. 
Significant overlap can be detected between each level, mainly in the case of relative height values (Figure 3). Terrace No. VI. fluctuates around $200 \mathrm{~m}$ relative height. The fluctuation is also significant in the case of absolute height values. Terrace No. III., which can be mapped well on such a scale, has the smallest fluctuation.

Looking at the histogram of the relative heights of the left side terraces, at least five distinct peaks can be distinguished, which is equal to the number of terrace surfaces identified by Kerekes, but elevation values are not matching. The peaks indicate surfaces with relative heights of 15, 50, 70, 105, 125 m. Significant separation can be observed between $150-240 \mathrm{~m}$. On the right side of the valley, instead of five, only three peaks can be observed, indicating surfaces with relative heights of 20, 50 and $100 \mathrm{~m}$. If we analyse the valley sides together, six peaks can be identified at a relative height of $15,45,70,95$, 105 and $125 \mathrm{~m}$. The asymmetric nature of the terrace system can also be observed when
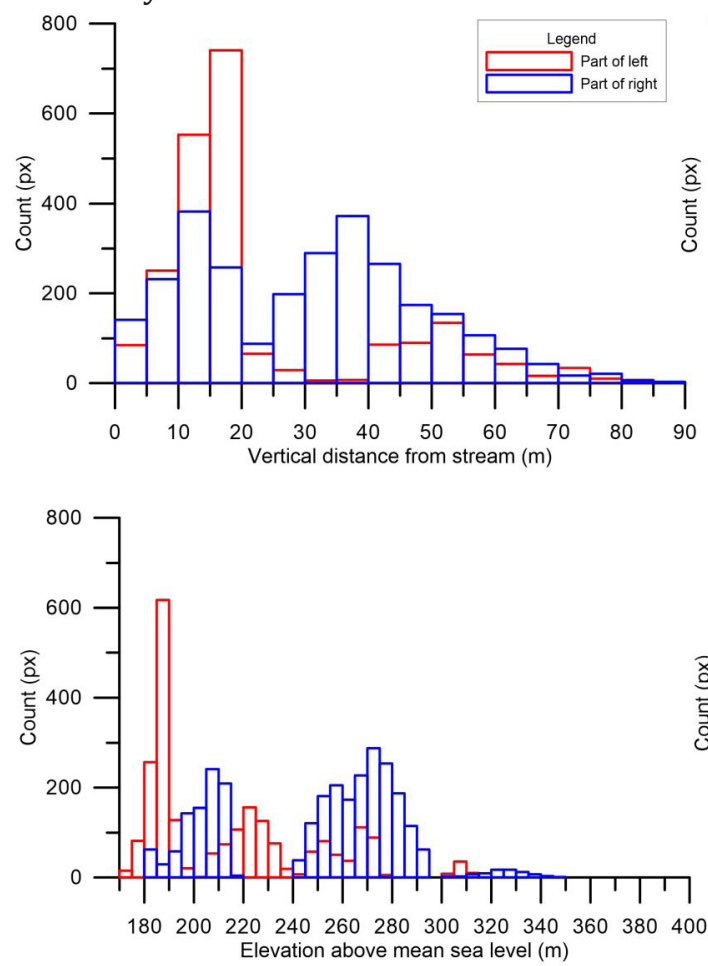

examining the elevation values (Figure 4).

\section{Analysis of the mapped terrace heights}

The elevation of the mapped gravel terraces varies between 0 and 90 m relative height and 160 and $400 \mathrm{~m}$ absolute height. Similarly, to the terraces mapped by Kerekes (1936), the asymmetric nature of the terrace system can be observed here as well (Figure 5). Based on the elevation histogram of the left side terraces of the stream, three peaks can be identified at relative heights of 20,55 , and $75 \mathrm{~m}$. On the right side, two peaks can be identified at a relative height of 15 and 40 $\mathrm{m}$. Examining the height of the terraces of the two valley sides together, we can observe a grouping with relative heights of $15 \mathrm{~m}$ and $40 \mathrm{~m}$. The reason for this is that the mapped gravel terrace No. III. is in a highly eroded state and there are only two gravel terraces in intact form. The third level can only be detected on the left side of the stream.
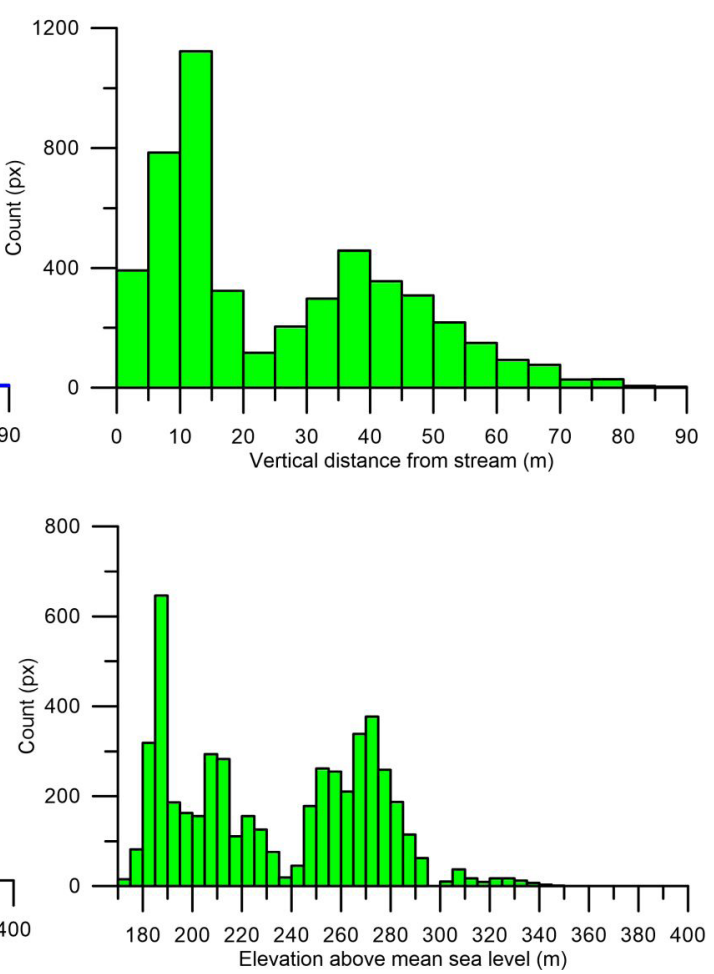

Fig. 5. Relative height and elevation of terraces mapped by Less et al. (2002) on the left (blue) and right (red) sides of the valley and altogether (green) 


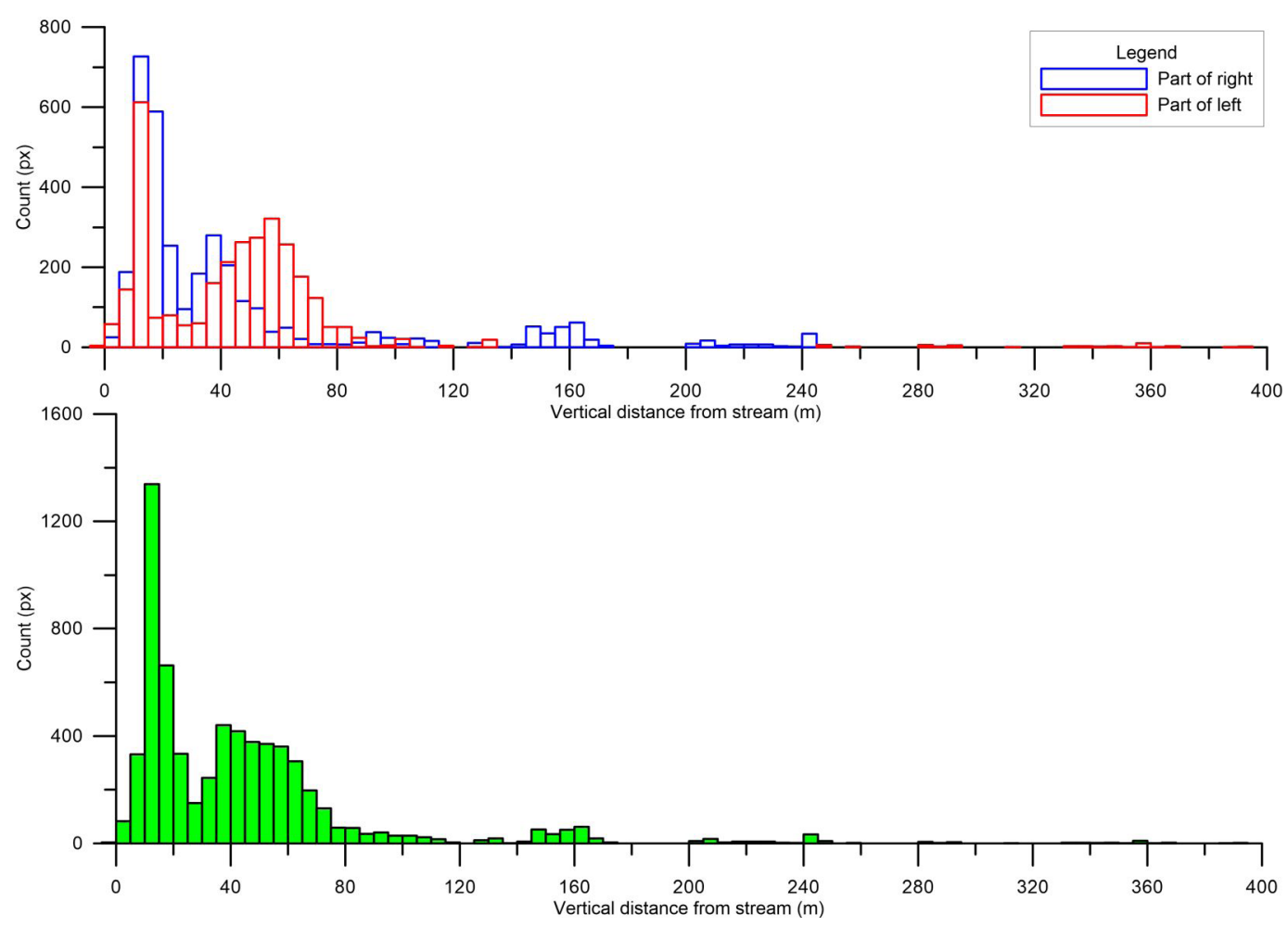

Fig. 6. Relative heights of remnant surfaces identified by morphometric analysis of DEM on the left(blue) and right (red) sides of the valley and altogether (green)

Height analysis of identified remnant surfaces

The delineated remnant surfaces (not only terraces!) are located between 0 and $400 \mathrm{~m}$ relative height and 175 and $575 \mathrm{~m}$ absolute height. The asymmetric nature of the valleys can also be observed (Fig. 6, Fig. 7). On the histogram showing the vertical distance (relative elevation) of the surfaces delineated

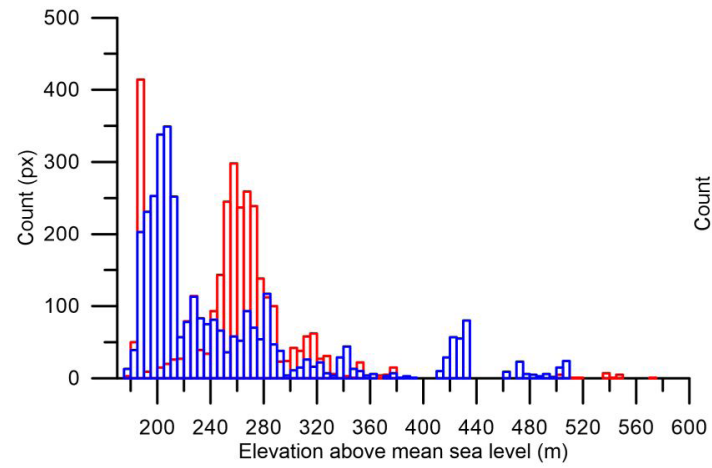

on the right side of the valley, ten peaks can be identified. The pixels are grouped around a relative height of $15,40,65,95,110,130$, $150,165,210,245 \mathrm{~m}$. These ten peaks on the histogram indicate strong tectonisation on the right valley side. However, on the left side, only four well-separable peaks can be observed at a relative height of 15 , $50,105,135 \mathrm{~m}$. Some pixels can be seen

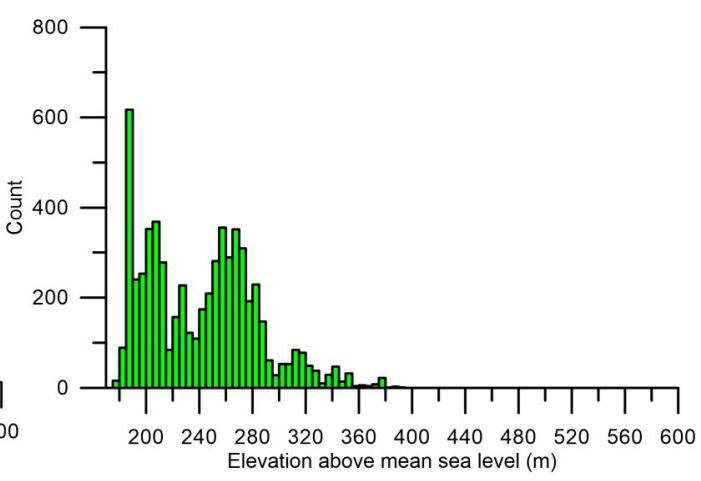

Fig. 7. Elevation of remnant surfaces identified by morphometric analysis of DEM on the left (blue) and right (red) sides of the valley and altogether (green) 

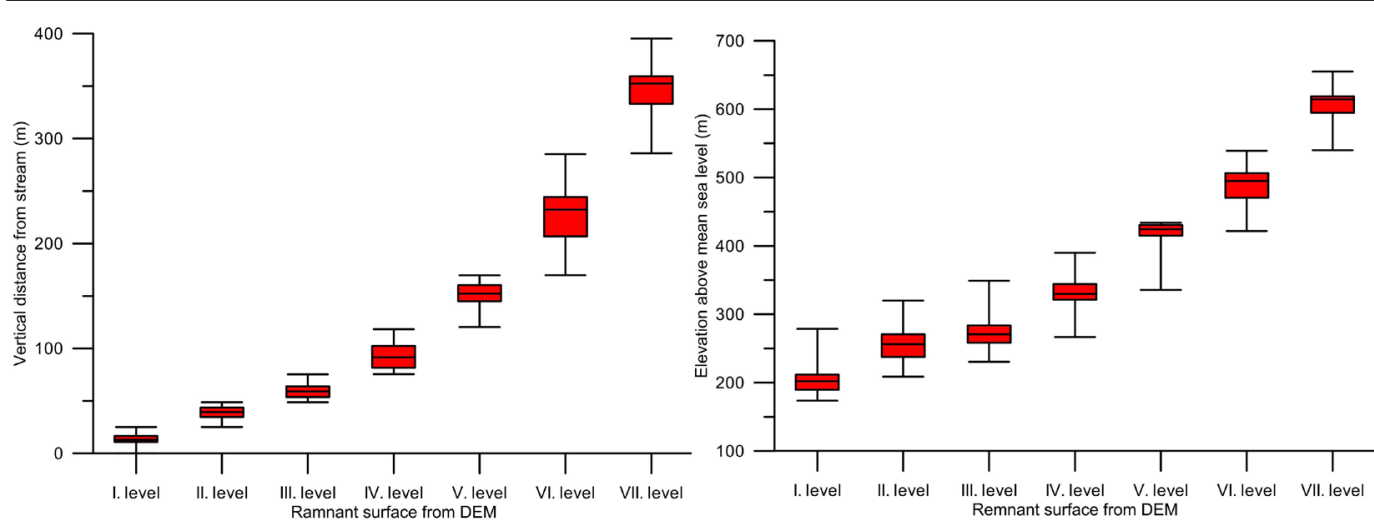

Fig. 8. Height distribution of remnant surfaces from DEM

between 245 and $400 \mathrm{~m}$. On the aggregated histogram, which includes both valley sides, we can identify only seven levels. In order to accurately delineate the boundaries of these seven remnant surfaces, the breaks of the histogram were automatically detected using the Natural Breaks (Jenks) command built into ArcGIS.

Based on the histogram, a reclassification was done (Fig. 9). The result shows that the lower three levels remained at the largest extent. In the most preserved form, the relatively youngest surface, the terrace No. I. remained with its $1.74 \mathrm{~km} 2$ area. This is followed by terraces No. II. and III., which have nearly the same area. These levels are interpreted as a terrace surface based on the presence of terrace gravel (Figure 10). Terrace No. IV. is very questionable, because at the height of this level terrace gravel rarely can be found; however, the rock terrace and the gravel material on it may have already been eroded. Based on the height of the surface, it can already be interpreted as a remnant of a pediment. The V. and VI. levels are indeed the remnants of the two pediment levels already identified in the Bükkalja (Dobos, 2006; Vágó \& Hegedûs 2011). The VII. level is the most questionable surface. At this height, near the Várkút spring, Legányi, the famous fossil hunter of Bükk Mountains found Helitherium sp. (Paralitherium tarkanyense), which age was defined by Kordos (1975) as Eocene. Kerekes (1938) considered the highest level of the Tárkány Basin to be a Miocene abrasion platform. Based on this, we assume that we managed to find remnants of a former abrasion platform at this height (Table 1).

There is no overlap in the relative heights of the delineated remnant surfaces, however, the older levels' heights (V., VI., VII.) fluctuate significantly. The lower three levels, which are also the largest in extent, show smaller fluctuations. In the case of elevation above sea

Table 1. The surface area of the reclassified remnant surfaces

\begin{tabular}{ccccc}
\hline Level & Area $\left(\mathrm{km}^{2}\right)$ & Area (\%) & Landform & Age \\
\hline I & 1,73625 & 40,90106 & terrace & \\
II & 0,969375 & 22,83569 & terrace & Quaternary \\
III & 1,075625 & 25,33863 & terrace & \\
\hline IV & 0,190625 & 4,490577 & terrace/pediment & Quaternary/Pliocene \\
\hline V & 0,179375 & 4,225559 & pediment & Pliocene \\
VI & 0,070625 & 1,663722 & pediment & Miocene -Eocene (?) \\
\hline VII & 0,023125 & 0,544759 & abrasion platform (?) & \\
\hline Sum & 4,245 & 100 & & \\
\hline
\end{tabular}




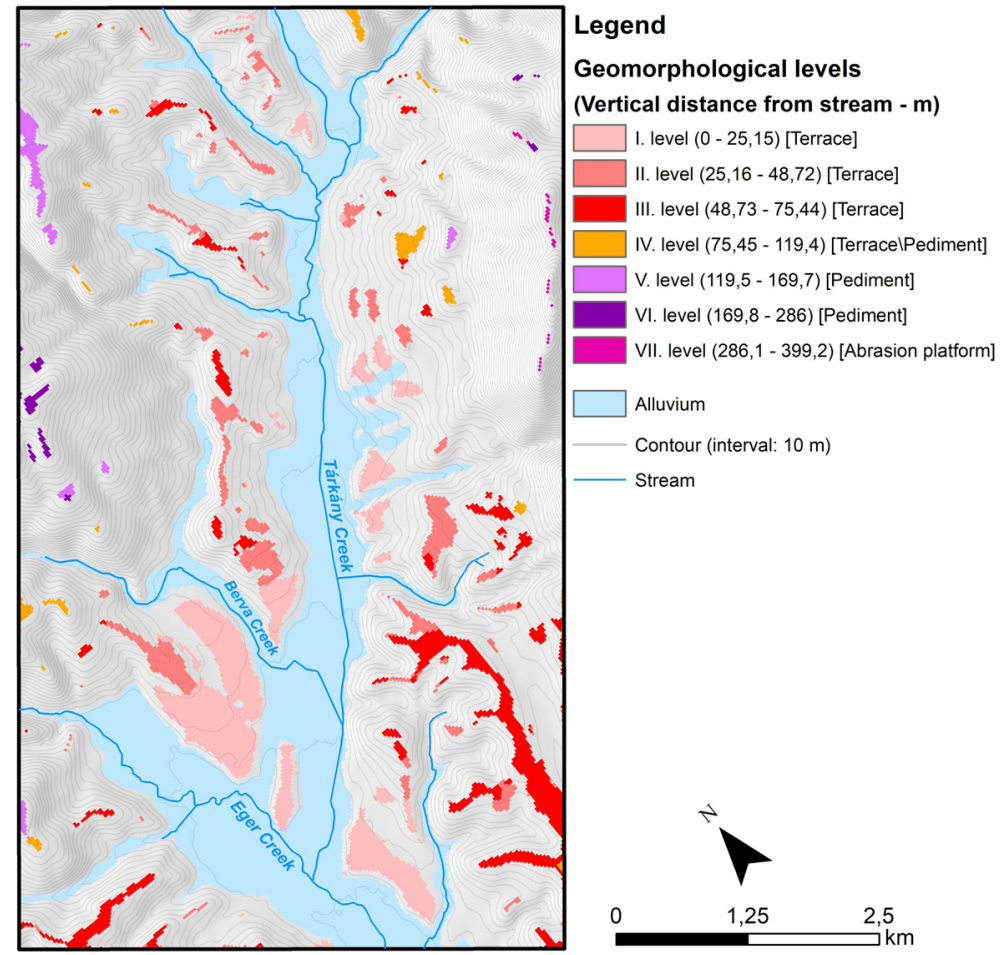

Fig. 9. 1:25000 scale geomorphological map of the Tárkány Basin

level, a significant overlap can be observed between the first five levels, however, the older surfaces can also be well separated on the basis of their absolute height (Figure 8).

However, it is important to note that these former levels might have been overridden/ eroded several times by tectonic movements, as indicated by the different number of terrace surfaces on the two valley sides.
$29 \%$ of the remnant surfaces of the Kerekes' map (1936) were identified using the DEM based method, which is $43 \%$ of the remnants delineated by our method (Figure10). The reason for the significant difference is that $57 \%$ of the surfaces delineated by Kerekes (1936) have a slope greater than $5^{\circ}$, however, in case of the DEM-based method, there are no surfaces with such a slope.

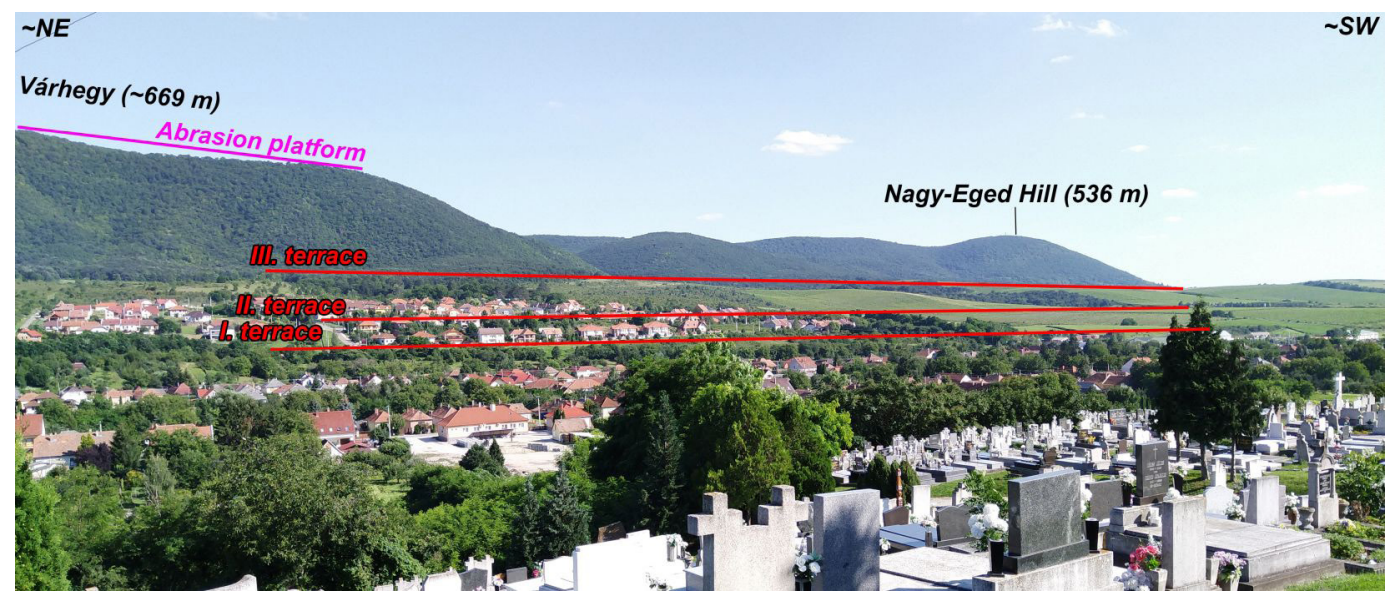

Fig. 10. The best-preserved remnant surfaces of the Tárkány Creek 


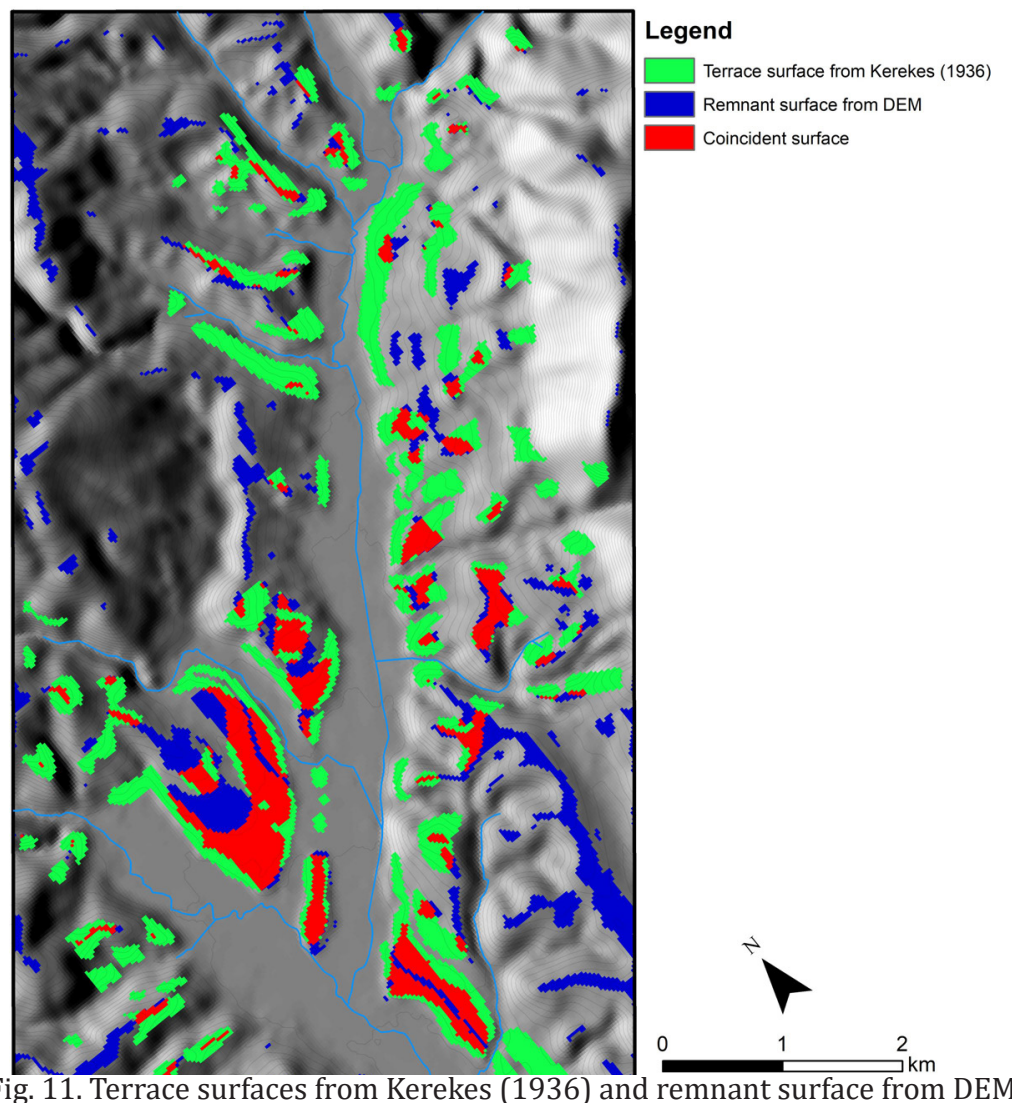

\section{Discussion}

The terraced valley of Tárkány Creek was noticed by geologists and geomorphologists very early (Schréter, 1912; Kerekes, 1936). Although these works were done with considerable precision, they were confined to the technical limitations of the age. Our examination proved this uncertainty in the height of the terraces delineated by Kerekes (1936). The height of the terraces identified by Kerekes (1936) fluctuated between the wide boundaries, especially the oldest surface. Recent geological studies (Less et al., 2002) had already provided a much more accurate picture of the gravel terraces in the area. However, their identification during the field investigations was also essential. The gravel material is marked on geological, and observation maps up to a relative height of 90 $\mathrm{m}$ above the valley bottom.

Based on the results of the literature, our field observations and morphometric examinations performed on a digital surface model; we managed to identify seven remnant surfaces in the Tárkány Basin. The first three levels were identified as terrace surfaces, as evidenced by the gravel material found on the terrain and marked on the geological maps. These surfaces have remained at the greatest extent. The status of level No. IV. is quite uncertain, it can be a terrace although at its height gravel material rarely can be found, or this surface may be a remnant of the pediment. The V. and VI. levels can be interpreted as remnants of the pediment. The VII. level might be interpreted as an abrasion platform.

The different elevation of the levels on the two valley sides and the multiple breaks in the histogram of the right-side terraces reveal an asymmetric terrace system and strong tectonisation. It is probable that 
the structural movements have already overridden the levels several times, creating mixed pediment/terrace levels. It confirms the results of previous studies, which characterise the valley of the Tárkány Creek as a structurally preformed valley (Petrik 2016), and many faults dissecting the basin can still be assessed as active (Pecsmány, 2020). In the recent phase of our research the remnant surfaces cannot be fit to the regional structural evolution of the Bükk Mts., it requires further investigations.

\section{Acknowledgements}

"The described article/presentation/study was carried out as part of the EFOP-3.6.1-162016-00011 "Younger and Renewing University - Innovative Knowledge City - institutional development of the University of Miskolc aiming at intelligent specialisation" project implemented in the framework of the Szechenyi 2020 program. The realization of this project is supported by the European Union, co-financed by the European Social Fund."

\section{References}

Balogh J. - Hevesi A. - Juhász Á. (1973): EgerFelnémet, Felszínalaktani és lejtőállapot térkép Eger Építésföldtani Térképsorozata. Eger-Felnémet - Geomorphological and slope stability map. Engeneering Geology maps of Eger city. 1: 10 000, Budapest. 2.

Condrad, O. (2011): Module TPI Based Landform Classification.

http://www.saga-gis.org/saga_tool_doc/2.2.5/ta_ morphometry_19.html

Condrad, O. (2013): Module Morphometric Features.

http://www.saga-gis.org/saga_tool_doc/2.2.5/ta_ morphometry_23.html

Dobos A. (2006): Az átmeneti (puffer)-zóna geológiai értékvédelmében játszott szerepének bemutatása az Egri-Bükkalja mintaterülete alapján. Importance of the Buffer-zone in case of geological values. The Southern Foothill of the Bükk Mts. (Bükkalja) as a study area. OTKA report. Collage of Károly Eszterházy, 42.

Dobos A. - Mester Zs. (2018): Felszínfejlődési rekonstrukciós vizsgálatok Eger környéki régészeti feltárások esetében. Landscape development reconstruction at archaeological excavations, case study in the Region Eger. Geographical Studies, Debrecen. 63-66.

Dövényi Z. (Ed.) (2010): Magyarország kistájainak katasztere. Cadastre of the regions of Hungary. Hungarian Academy of Sciences - Geographical, Budapest. 736-759.

Gábris Gy. (2006): A magyarországi folyóteraszok kialakulásának és korbeosztásának magyarázata az oxigénizotóp-sztratigráfiai tükrében. Explanation of River Terrace Formation and Chronology in Hungary in the Light of Oxygen Osotope Stratigraphy. Hungarian Geographical Review. 130 (54) 3-4, 123-133.

Gál P. - Pecsmány P.- Petrik A. - Lukács R: - Fodor L. Kövér Sz. - Harangi Sz. (2019): A Mátraés a Bükk határvidékét borító miocén képződmények újratérképezése. Geological remapping of the Miocene sedimentary-volcanic basin at the border area of the Mátra and Bükk Mountains. 10th Assembly of Petrology and Geochemistry. 45.

Gál P. - Pecsmány P. - Petrik A. - Lukács R: - Fodor L. Kövér Sz. - Harangi Sz. (2019): Geological and geomorphological remapping of the Miocene sedimentary-volcanic basin at the border area of the Mátra and Bükk Mountains (NE Hungary), 14th. Workshop of the International Lithosphere Program Task Force Sedimentary Basins. Abstract. 32-34.

Gulácsi Z. (n. d.): Geological observation map. ÉMoSzR. 308-22. Felsőtárkány.

Jenness, J. (2006): Topographic Position Index (tpi jen.avx) extension for ArcView 3.x, v. 1.3a. http://www.jennessent.com/arcview/TPI jen_poster.htm

Katona G. (2017): Preliminary analysis of heterogeneous Fault-Slip Systems in the Felnémet Limestone Quarry. University of Miskolc. PhD Forum. 33-41.

Kerekes J. (1936): A Tárkányi-öböl morfológiája. Geomorphology of Tárkány Basin. Hungarian Geographical Review, Budapest, 80-67.

Kerekes J. (1938): Az egerkörnyéki barlangvidék kialakulása. (The formation of the cave area near Eger). Barlangkutatás (Speleology) 16(1). 90-139.

Kordos L. (1975): Új felső-eocén sziréna [Paralitherium tarkanyense n. g. n. $\quad$ sp.] Felsőtárkányból. The new Upper Eocene Haliterium (Paralitherium tarkanyense n. g. n. sp.) from Felsőtárkány. Hungarian Institute of GeologyAnnual Report. 349-367. 
Krolopp E. - Schweitzer F. - Scheuer Gy. - Hably L. - Skoflek I. - Kordos L. (1989): Az egri pleisztocén édesvízi mészkő geomorfológiai, paleohidrológiai és őslénytani vizsgálata. Geomorphological, paleohydrological and paleontological studies of travertine from the Eger Pleistocene. Bull of the Hungarian Geol. Soc. 119, 5-29.

Less GY. - Gulácsi Z. - Kovács S. - Pelikán P. - Pentelényi L. - Rezessy A. - Sásdi L. (2002): Geological map of Bükk Mts. Hungarian Institute of Geology, Budapest.

Less GY. - Kovács S. - Pelikán P. - Pentelényi L. - Sásdi L. (2005): A Bükk hegység földtana. Geology of Bükk Mts. Pelikán P. (Ed.) - Hungarian Institute of Geology, Budapest. 249.

Pecsmány P. (2017): Felszínalaktani és fejlődéstörténeti vizsgálatok a Bükkalján, különös tekintettel a völgyhálózat kialakulására. Reconstruction of landscape development and geomorphological studies in the Bükkalja, in particular the development of the valley system. Msc Thesis, Miskolc. 90 .

Pecsmány P. (2020): A bükkaljai vízfolyások kanyarulat-fejlettségének vizsgálata: szerkezetföldtani okok és következtetések. An Analalysis of the sinuosity index of Stream Channels in the Bükkalja: Structural Geological causes and conclusions. Hungarian Geographical Review. DOI: 10.32643/ fk.144.2.1 - 144. 2. 133-152.
Petrik A. (2016): A Bükk déli előterének kainozoos szerkezetalakulása. Cenozoic Structural Evolution of the Southern Bükk Foreland. PhD Thesis. ELTE-TTK. Budapest, 264.

Pinczés Z. (1955): Morfológiai megfigyelések a Hór völgyében. Geomorphological invertigation in the Hór Valley. Hungarian Geographical Bulletin IV, 145-156.

Pinczés Z. (1957): Az Eger-völgy problémái. Geomorphological Problems of The Eger Valley. Hungarian Geographical Bulletin. VI, 29-43.

Schréter Z. (1912): Eger könyékének földtani viszonyai. Geological settings of the Eger Regions. MÁFI report. 130-146.

Weiss, A. (2001): Topographic Position and Landforms Analysis - Poster presentation, ESRI User Conference, San Diego, CA. http:// www.jennessent.com/downloads/tpi-postertnc_18x22.pdf

Vágó J. - Hegedűs A. (2011): DEM based examination of Pediment Levels: a case study in Bükkalja, Hungary. Hungarian Geographical Bulletin 60 (1), 25-44. 